\title{
Changing Structure of Out-put \& Employment from Primary to Non-primary Sectors of J\&K Economy \& Kuznets Analysis (1981-2011)
}

\author{
Bilal Ahmad Sheikh \\ Research Scholar (Ph.D), Department of Economics, University of Kashmir
}

\begin{abstract}
Kuznets analysis of Changing Structure of Out-put from Primary to Non-primary sectors of economy is feasible only if this shift leads to improvement in the growth rates in both the sectors of the economy. The shift of workforce from primary to non-primary sectors has also calculated so as to check the productivity and income equalities in the key sectors of J\&K state economy. The Changing Structure of Out-put \& employment from Primary to Non-primary Sectors is viable for J\&K economy as it has lead to the improvement in the growth rates of both the sectors of the state economy.
\end{abstract}

Keywords: Primary sector, Non-Primary Sector (secondary and tertiary sectors), NSDP, Kuznets Analysis, Linking Factor Method, growth rates.

\section{Introduction}

Jammu and Kashmir State is the northern most state of India. It is situated mostly in the Himalayan Mountains. J\&K State shares a border with the states of Himachal Pradesh and Punjab to the south and internationally with China to the north and east and the Pakistan occupied Kashmir and Gilgit-Baluchistan, to the west and northwest respectively.

The Jammu and Kashmir state is bestowed with natural glamour of snow-clad mountains, lakes, streams and rare flora and fauna and holds a prospering tourism sector. Famous for small-scale and cottage industries including carpet weaving, silks, and copper and silverware, the state economy's 58.52 percent workforce is directly dependent upon the non-primary sector which represents the importance of the sector for the economy.

Output \& Employment Percentage Share of Primary Sector in J\&K State Economy (1981-2011)

Primary sector of an economy is the sector making direct use of natural resources ${ }^{1}$. Most products from this sector provide raw materials for other industries. This sector includes subsectors like agriculture including livestock, forestry \& Logging, fishing, mining and quarrying.

The share of primary sector in $J \& K$ state economy has decreased from the past three decades. The percentage contribution of primary sector to NSDP at constant prices has decreased continuously during the period of analysis, from 47.37 percent in 1980-81 to 38.44 percent in 1990-91 to 32.56 percent in 2000-01 and finally to 21.98 percent in 2010-11.There has been a slow and continuous fall in the percentage share of labor force employed in primary sector since 1981 upto 2011. In 1981 the total labor force employed in primary sector was $63.88 \%$ which declined to $57.96 \%, 50.1 \%$ and $41.48 \%$ in 1991, 2001 and 2011 respectively. The output and employment share do not move at the same speed in the same direction. In other words, there is inequality in the shift of out-put and employment in the primary sector of the economy which is a negative sign for the Jammu \& Kashmir economy as it represents the presences of income and productivity inequalities in the primary sector on the one hand and economy as a whole on the other hand. The statements are corroborated by the analysis of the data as shown in Table 1.1

Table 1.1: Classification of output and Workforce in J\&K State Economy by Primary Sector (\%) (1981-2011)

\begin{tabular}{|c|c|c|c|c|}
\hline Year (Decadal) & 1981 & 1991 & 2001 & 2011 \\
\hline Workforce in primary sector (in \%) & 63.88 & 57.96 & 50.1 & 41.48 \\
\hline Out-put of primary sector (in \%) & 47.40 & 38.47 & 32.59 & 21.98 \\
\hline
\end{tabular}

Sources: 1) Economic census, Govt. of India, various issues.

${ }^{1}$ Oxford Dictionary of Economics by John Blakes, Nigar Hashimzade and Gareth Myles. 
2) Digest of Statistics; Directorate of Economics and Statistics; Govt. of J\&K, various issues.

From the above table, it becomes clear that there is a presence of asymmetry between the output and employment share in the primary sector. In 1980-81, 63.88 percent workforce possessed 47.40 percentage share from the state income while in 2010-11, 41.48 percentage workforce possessed 21.98 percentage income share. Therefore, a decline in workforce by about 22 percentage points associated with a fall of about 25 percentage points in output of primary sector leads to both income and productivity inequalities.

Figure 1.1: $\quad$ Graphical Representation of Table

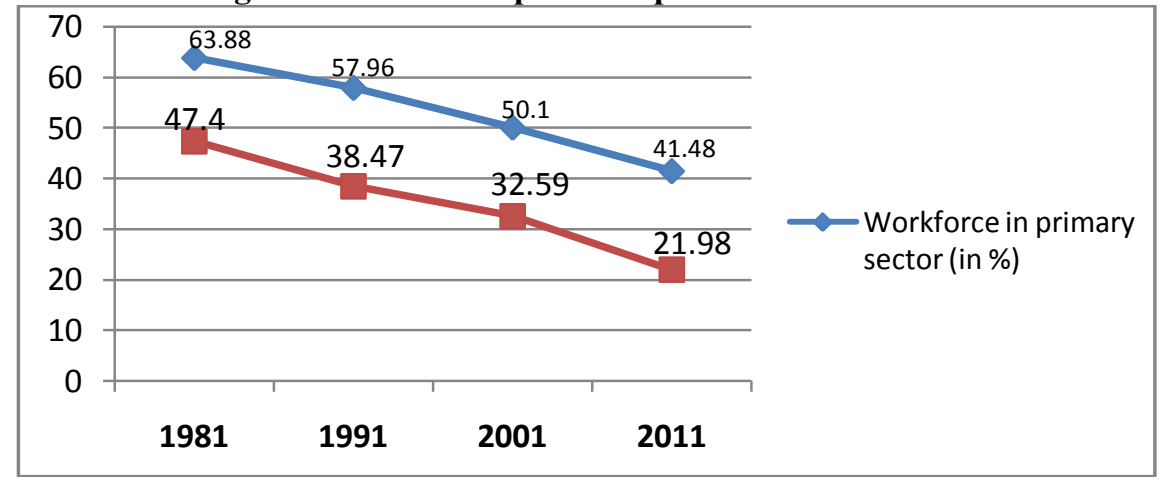

From the above figure, it becomes clear that there is a continuous decline in the percentage of both out-put and work force of primary sector, but the fall in the out-put is more steeper than the fall in the work force which is not a good sign for J\&K state economy as it represents low degree of income and productivity equalities.

\section{Output \& Employment Percentage Share of Non-Primary Sector in J\&K State Economy (1981-2011)}

Non-primary sector of an economy is the sector making use of out-put of primary sector as input. This sector comprises of secondary and tertiary sectors. The share of out-put and employment of non- primary sector in J\&K state economy has increased continuously from the past three decades. But, the percentage increase in out-put share is more rapid as compared to the percentage increase in employment share.

The percentage share of out-put of non- primary sector to NSDP at constant prices has increased from 52.6 percent in 1980-81 to 61.53 percent in 1990-91 to 67.41 percent in 2000-01 and finally to 78.02 percent in 201011.There has been a lit bit slower increase in the percentage share of labor force employed in non- primary sector since 1981 upto 2011. In 1981 the total labor force employed in non-primary sector was $36.12 \%$ which inclined to $42.04 \%, 49.90 \%$ and $58.52 \%$ in 1991, 2001 and 2011 respectively. The output and employment share has almost moved at the same speed to the same direction. In other words, there is equality in the shift of out-put and employment in the non-primary sector of the economy which is a positive sign for the Jammu \& Kashmir economy as it represents the presences of income and productivity equalities in the primary \& non-primary sectors on the one hand and economy as a whole on the other hand. But, there is still a marginal gap between out-put and employment shares in the non-primary sector in the state economy. The statements are corroborated by the analysis of the data as shown in Table 1.2

Table 1.2: Classification of output and Workforce in J\&K State Economy by Primary Sector (\%) (1981-2011)

\begin{tabular}{|c|c|c|c|c|}
\hline Year (Decadal) & 1981 & 1991 & 2001 & 2011 \\
\hline Workforce in non- primary sector (in \%) & 36.12 & 42.04 & 49.90 & 58.52 \\
\hline Out-put of non-primary sector (in \%) & 52.6 & 61.53 & 67.41 & 78.02 \\
\hline
\end{tabular}

Sources: 1) Economic census, Govt. of India, various issues.

2) Digest of Statistics; Directorate of Economics and Statistics; Govt. of J\&K, various issues.

From the above table, it becomes clear that there is still the presence of asymmetry between the output and employment share in the non-primary sector. In 1980-81, 36.12 percent workforce possessed 52.6 percentage share from the state income while in 2010-11, 58.52 percentage workforce possessed 78.02 percentage income share. Therefore, an incline in workforce by about 22 percentage points associated with a rise of about 25 percentage 
points in output of non- primary sector leads to increase in 2 percentage points in both income and productivity inequalities.

\section{Objectives}

Some of the explicit objectives of the study are as under:

1. To analyze the changes in volume and composition of output in the primary and non-primary sectors of the state economy.

2. To analyze the changes in volume and composition of employment in the primary and non-primary sectors of the state economy.

\section{Data and Methodology}

The study is primarily based on the secondary data that is obtained from the following sources: -

- Economic census, Govt. of India, various issues.

- Digest of statistics; Directorate of Economics and Statistics; Govt. of J\&K, various issues.

- Economic Survey; Directorate of Economics and Statistics; Govt. of J\&K, various issues.

- Economic Review of J\&K; Directorate of Economics and Statistics; Govt. of J\&K, 2007-08.

- Reports, journals, magazines and news papers.

In addition to the above sources relevant information has been collected from the following departments:

- Directorate of Economics, Statistics \& planning, Govt. of Jammu and Kashmir, Srinagar.

- Directorate of Sericulture, J\&K, Srinagar.

- Directorate of Handicrafts, J\&K, Srinagar.

- Directorate of Handlooms, J\&K, Srinagar.

- Labour Commissioner, J\&K, Srinagar.

- Financial Commissioner (Rev), J\&K, Srinagar.

The following appropriate statistical tools have been used to analyze the data:

1) Linking Factor Method: It is a method through which base year is changed or rebase is formed .It is simply done by using the following two formulas:

a) Deflator $=($ Factor $) \times($ Out-put level of the corresponding year $)$

Whereas; $\quad$ Factor $=($ Old Base $) \div($ New Base $)$

b) Inflator $=($ Factor $) \times($ Out-put level of the corresponding year $)$

Whereas; $\quad$ Factor $=($ New Base $) \div($ Old Base $)$

\section{2) Changing Structure of J\&K economy \& Kuznets Analysis}

In order to show the importance of transformation from primary sector to non-primary sector, the following Kuznets equations have been used.

$\mathrm{Pp}=$ primary sector net product

$\mathrm{Pn}=$ non-primary sector net product (i.e. secondary \& tertiary sectors)

$\mathrm{P}=$ total national product

$\mathrm{P}=\mathrm{Pp}+\mathrm{Pn}$

Then

$\mathrm{P}=\mathrm{Pp}+\mathrm{Pn}$

and

$\Delta \mathrm{P}=\Delta \mathrm{Pp}+\Delta \mathrm{Pn}$

$\Delta \mathrm{P}=(\Delta \mathrm{Pp} / \mathrm{Pp}) \mathrm{Pp}+(\Delta \mathrm{Pn} / \mathrm{Pn}) \mathrm{Pn} \ldots . .(2)$

Writing $\mathrm{rp}$ for $\Delta \mathrm{Pp} / \mathrm{Pp}$, rn for $\Delta \mathrm{Pn} / \mathrm{Pn}$ :

$\Delta \mathrm{P}=$ Pprp + Pnrn

$\mathrm{Pp} \mathrm{rp}=\Delta \mathrm{P}-\mathrm{Pnrn}$

$\frac{\mathrm{Pp} \mathrm{rp}}{\Delta P}=\frac{\Delta \mathrm{P}}{\Delta \mathrm{P}}-\frac{\mathrm{Pnrn}}{\Delta \mathrm{P}}$.

$\frac{\mathrm{Pp} \mathrm{rp}}{\Delta P}=1-\frac{\mathrm{Pnrn}}{\Delta \mathrm{P}}$

Substituting for $\Delta \mathrm{P}$ on the RHS of equation (5) from equation (3):

$\frac{\text { Pp rp }}{\Delta P}=1-\frac{\text { Pnrn }}{\text { Pprp }+ \text { Pnrn }}$ 
$\frac{\text { Pp rp }}{\Delta P}=\frac{\text { Pprp }+ \text { Pnrn }- \text { Pnrn }}{\text { Pprp }+ \text { Pnrn }}$

$\frac{\text { Pp rp }}{\Delta P}=\frac{\text { Pprp }}{\text { Pprp }+ \text { Pnrn }}$

$\frac{\text { Pp rp }}{\Delta P}=\frac{1}{(\text { Pprp }+ \text { Pnrn }) / \text { Pprp }}$

$\frac{\text { Pp rp }}{\Delta P}=\frac{1}{1+\text { Pnrn } / \text { Pprp }}$

Kuznets formula expressing an inverse relationship between primary sector's share of GDP growth (Pprp/ $\Delta \mathrm{P})$ and the product of the ratio of sectoral shares of GDP $(\mathrm{Pn} / \mathrm{Pa})$ and the ratio of sectoral growth rates (rn/ra) is given by equation (6).

3) Growth Rate: Simple, average and compound growth rates have been calculated with the help of the following formulas:

a) Annual Growth Rate or Simple Growth Rate: The annual growth rates for a series of T annual observations, say $y_{1}, y_{2}, y_{3}, \ldots y_{t}$ is defined as

$a_{t}=\frac{y_{t}-y_{t-1}}{y_{t-1}}$

Whereas; $y_{t}$ refers current year out-put

$y_{t-1}$ refers previous year out-put

b) Average Annual Growth Rate: The average growth rate has been calculated with the help of following formula:

Average Annual Growth Rate $=(1 / \mathrm{T}) * \operatorname{Ln}\left(\mathrm{Y}_{\mathrm{t}} / \mathrm{Yi}\right) * 100$

Whereas; T refers number of times we see increase or decrease over the time period.

$\mathrm{Ln}$ is the natural logarithm

$\mathrm{Y}_{\mathrm{t}}$ refers variable in final time period

Yi refers variable in initial time period

Table1.3: Shift of Employment Percentage Share from Primary to Non-Primary Sector in J\&K State Economy (1981-2011)

\begin{tabular}{|c|c|c|c|c|}
\hline Year (Decadal) & 1981 & 1991 & 2001 & 2011 \\
\hline Workforce in primary sector (in \%) & 63.88 & 57.96 & 50.1 & 41.48 \\
\hline Workforce in non- primary sector (in \%) & 36.12 & 42.04 & 49.90 & 58.52 \\
\hline Total & 100 & 100 & 100 & 100 \\
\hline
\end{tabular}

Sources: Census of India, various Issues

Note: Data for 1991 has been interpolated

The employment percentage share of primary sector has decreased continuously during the entire reference time period. It has decreased from 63.88 percent in 1981 to 41.48 percent in 2011 while as in non-primary sector percentage share has increased from 36.12 percent in 1981 to 58.52 percent in 2011 . Therefore, there is 22.40 percentage points shifts of employment from primary sector to non-primary. 


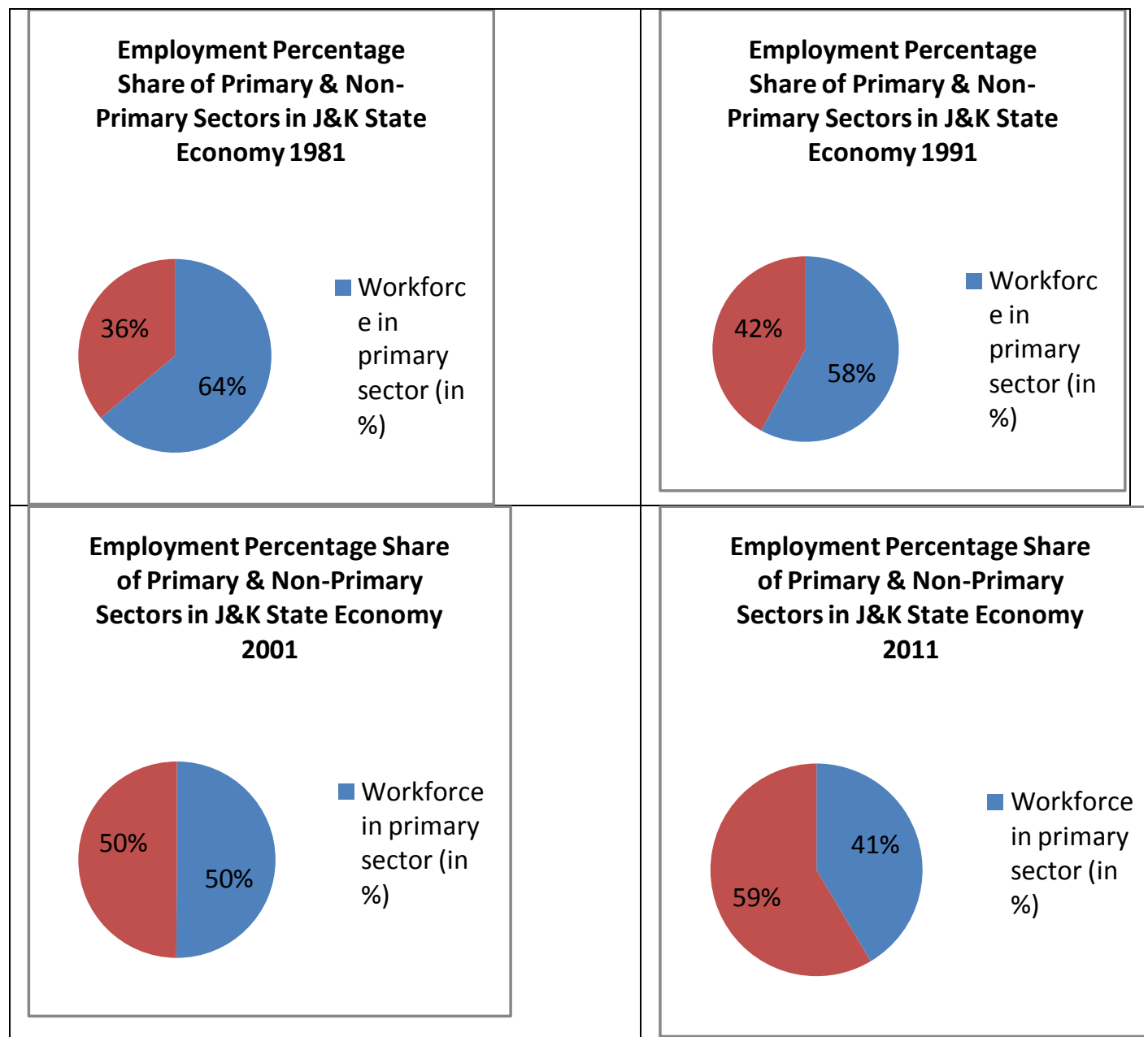

\section{Performance of Primary and Non-primary Sectors of J\&K State Economy}

Table-1 shows the absolute sectoral share in NSDP. At current prices, in 1980-81 the share of primary sector was Rs.497.44 crores which increased to Rs.9225.98 crores in 2010-11,showing an increase of 18.55 times while as at constant prices (at 1993-94 prices), in 1980-81, the absolute share of primary sector was Rs.1798.04 crores which increased to Rs.3819.74 crores in 2010-11, showing an increase of 2.12 times

While as the absolute sectoral share in NSDP. At current prices, in 1980-81 the share of non-primary sector was Rs.554.49 crores which increased to Rs.54490.4 crores in 2010-11, showing an increase of 98.36 times while as at constant prices (at 1993-94 prices), in 1980-81, the absolute share of non-primary sector was Rs. 1506.06 crores which increased to Rs.9083.49 crores in 2010-11, showing an increase of 6.03 times (refer Table 1)

Similarly Table-1.4, depicts sectoral percentage shares in NSDP. At current prices, in 1980-81 the percentage share of primary sector was $47.29 \%$ which decreased to 22.01 percent in $2010-11$, showing a decrease of almost 25 percentage points while as at constant prices (at 1993-94 prices), in 1980-81, the percentage share of primary sector was 47.40 percent which decreased to $21.59 \%$ in $2010-11$, showing a decrease of almost 25 percentage points.

While as the percentage sectoral share in NSDP. At current prices, in 1980-81 the percentage share of nonprimary sector was 52.71 percent which increased to 78.90 percent in 2010-11,showing an increase of almost 26 percentage points while as at constant prices (at 1993-94 prices), in 1980-81, the percentage share of non-primary sector was 59.70 percent which increased to 78 percent in 2010-11, showing an increase of 18.percentage points (refer to Table 1.4). 
Table 1.4: Percentage Share of Primary and Non-primary Sectors in NSDP to State Economy (1981-2011)

\begin{tabular}{|c|c|c|c|c|c|}
\hline \multicolumn{2}{|c|}{$\begin{array}{c}\text { Primary Sector } \\
\text { (in Percentage) }\end{array}$} & \multicolumn{2}{c|}{$\begin{array}{c}\text { Non-Primary Sector } \\
\text { (in Percentage) }\end{array}$} & \multicolumn{2}{c|}{$\begin{array}{c}\text { NSDP } \\
\text { (in Percentage) }\end{array}$} \\
\hline Cn.Prices & Ct.Prices & Cn.Prices & \multicolumn{1}{c|}{ Ct.Prices } & Cn.Prices & \multicolumn{1}{c|}{ Ct.Prices } \\
\hline 47.40 & 47.29 & 52.60 & 52.71 & 100 & 100 \\
\hline 44.84 & 41.19 & 55.16 & 58.81 & 100 & 100 \\
\hline 38.47 & 43.29 & 61.53 & 56.71 & 100 & 100 \\
\hline 39.58 & 38.06 & 60.42 & 61.94 & 100 & 100 \\
\hline 32.58 & 33.01 & 67.42 & 66.99 & 100 & 100 \\
\hline 30.70 & 29.03 & 69.30 & 70.97 & 100 & 100 \\
\hline 21.98 & 21.10 & 78.02 & 78.90 & & 100 \\
\hline
\end{tabular}

Source: based on Table 1

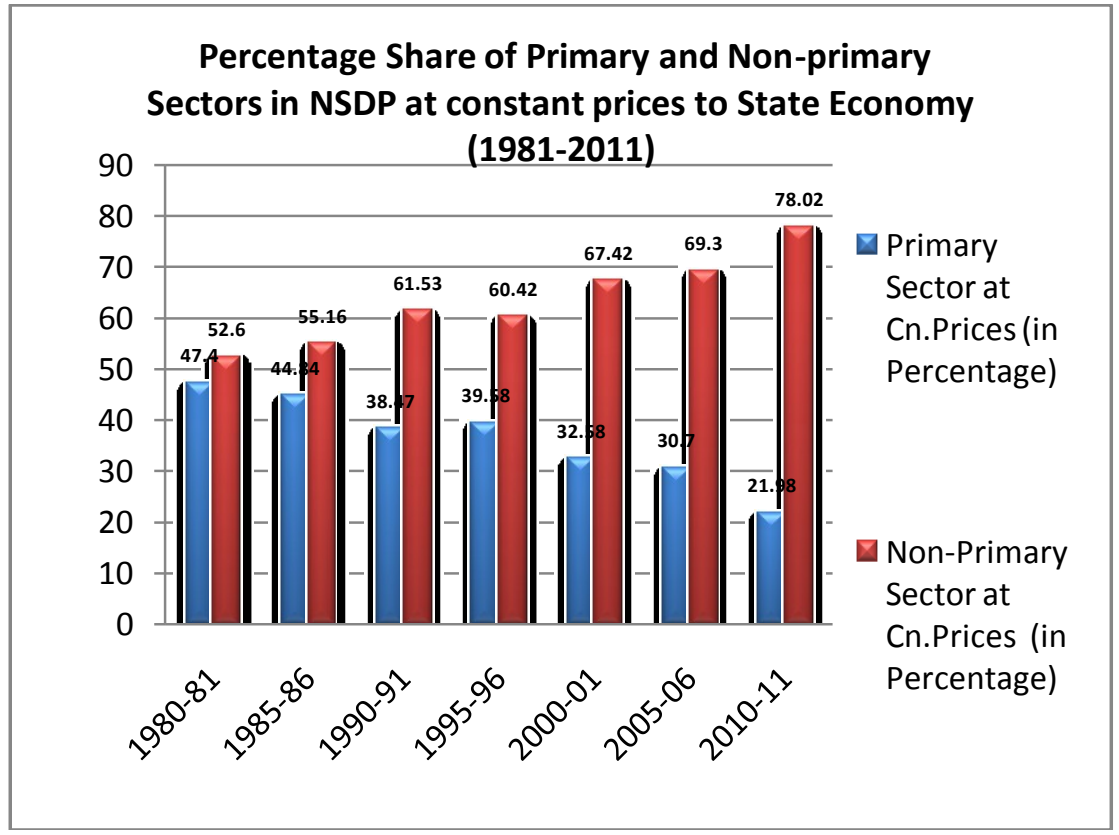

Table 1.5: Changing Structure of J\&K Economy \& Kuznets Analysis

\begin{tabular}{|c|c|c|c|c|c|c|c|c|c|c|c|c|c|c|c|}
\hline \multicolumn{2}{|c|}{$\mathbf{P p}$} & \multicolumn{2}{|c|}{ Pn } & \multicolumn{2}{|c|}{$\mathbf{R p}$} & \multicolumn{2}{|c|}{ rn } & \multicolumn{2}{|c|}{$\mathbf{P n} / \mathbf{P p}$} & \multicolumn{2}{|c|}{$\mathbf{r n} / \mathbf{r p}$} & \multicolumn{2}{|c|}{$\begin{array}{c}(\mathrm{Pn} / \\
\mathrm{Pp})(\mathbf{r n} / \mathbf{r p})\end{array}$} & \multicolumn{2}{|c|}{$\begin{array}{c}(\mathbf{P p} \times \\
\mathbf{r p}) / \Delta \mathbf{p}\end{array}$} \\
\hline$\stackrel{\vec{\infty}}{\Omega}$ & $\overline{\vec{\nu}}$ & $\begin{array}{l}\bar{\infty} \\
\stackrel{\Omega}{2}\end{array}$ & $\bar{\Xi}$ & $\frac{\mathfrak{a}}{\infty}$ & 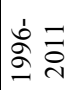 & $\frac{\mathfrak{a}}{\mathfrak{\alpha}}$ & $\begin{array}{l}\stackrel{1}{\circ} \bar{\sigma} \\
\stackrel{1}{\circ}\end{array}$ & $\vec{\infty}$ & $\vec{\nabla}$ & $\begin{array}{l}\vec{\infty} \\
\stackrel{9}{0}\end{array}$ & $\overline{\vec{i}}$ & $\begin{array}{l}\vec{\infty} \\
\stackrel{-}{2}\end{array}$ & $\overrightarrow{\vec{i}}$ & $\vec{\infty}$ & $\overrightarrow{\bar{i}}$ \\
\hline 0.47 & $\begin{array}{c}0.2 \\
2\end{array}$ & 0.53 & 0.78 & 2.41 & $\begin{array}{l}3 . \\
5\end{array}$ & 4.14 & 9.48 & 1.13 & 3.55 & $\begin{array}{c}1.7 \\
2\end{array}$ & $\begin{array}{c}2.7 \\
1\end{array}$ & $\begin{array}{c}1.9 \\
4\end{array}$ & 9.62 & $\begin{array}{c}2.2 \\
7\end{array}$ & $\begin{array}{c}1.5 \\
4\end{array}$ \\
\hline
\end{tabular}

Source: based on Table 1

$P p=$ Primary sector $\%$ share of NSDP

$P n=$ Non- Primary sector share of NSDP

$r p=$ Average annual growth rate of Primary sector product

$r n=$ Average annual growth of non- Primary sector product.

$(P p / r p) / \triangle p=$ Ratio of Primary sector to NSDP growth (derive from Pp, Pn, rp, rn using Kuznets formula)

$\triangle P / p=$ Average annual growth rate of NSDP

TE: Triennium Average

The above table clearly confirms various types of correlations explained by Kuznets model of Structural transformation from primary to non-primary sector. The various types of correlations are as: 
The percentage share of primary sector and the growth rate of primary sector are inversely related to each other. The percentage share of primary sector was $47 \%$ in 1981 where as the growth rate of primary sector was $2.41 \%$ in the same time period. The percentage share decreased to $22 \%$ of primary sector in 2011 while as the growth rate of the primary sector increased to $3.5 \%$ in the same time period. Therefore, shift of percentage share from primary to non-primary sector leads to increase in the growth rate to the same sector which is a viable shift for the overall economy.

The percentage share of primary sector and the growth rate of non-primary sector are negatively related to each other. The percentage share of primary sector was $47 \%$ in 1981 where as the growth rate of non-primary sector was $4.14 \%$ in the same time period. The percentage share decreased to $22 \%$ of primary sector in 2011 while as the growth rate of the non-primary sector increased to $9.48 \%$ in the same time period. Therefore, shift of percentage share from primary to non-primary sector leads to increase in the growth rate of non-primary sector which is a viable shift for the overall economy.

The growth rate of primary sector and the growth rate of non-primary sector are directly related to each other. The growth rate of primary sector was $2.41 \%$ in 1981 where as the growth rate of non-primary sector was $4.41 \%$ in the same time period. The growth rate increased to $3.5 \%$ of primary sector in 2011 while as the growth rate of the non-primary sector increased to $9.48 \%$ in the same time period.

Therefore, the ratio of non-primary percentage share to primary has increased from 1.13 to 3.55 where as the ratio of growth rate of non-primary to primary sectors has increased from 1.72 to 2.71 .

The Table again confirms the Kuznets model of inverse relation between $(\mathrm{Pn} / \mathrm{Pp})(\mathrm{rn} / \mathrm{rp})$ and $(\mathrm{Pp} \times \mathrm{rp}) / \Delta \mathrm{p}$.

Therefore, from the above discussion it becomes clear that the structural change from primary to non-primary sector is viable as it increases the growth rate of both the sectors of the state economy.

\section{Conclusion}

The structural change from primary to non-primary sector has lead to increase in the growth rate of both the sectors of the state economy. But, the growth rate of primary sector has not improved so much, i.e; it has not crossed 5\% growth rate mark during the entire period. This is really a matter of concern for J\&K state economy. The causes of slow growth rate of primary sector which policy makers have to address are:

i. Low Seed Replacement Ratio (SRR) in case of High Yielding Varieties (HYV) of major crops is yet to surpass $15 \%$ in comparison to the national level SRR of above $25 \%$. To sustain continuous growth in productivity, SRR \& seed management play a crucial role ( Economic Survey, Planning \& Development Department, Govt. of Jammu \& Kashmir, 2010-11).

ii. The agriculture sector faces challenges on many fronts. On the supply side; the yield of most crops is not improving. It needs to mention here that yield of food crops is stagnant at around 14 quintals per hectare based on last 30 years average figure. Regarding some cases it fluctuates downwards. The cultivable area is about $8 \%$ of geographical area and $34 \%$ of the reporting area; net area sown constitutes only $30 \%$ of the reporting area. The scope for increase in the net area sown is limited rather bleak. Farm size is continuously shrinking (Digest of Statistics, Planning \& Development Department, Govt. of Jammu \& Kashmir, 2010-11)

iii. Availability of irrigation facility is restricted to $44 \%$ of the net area sown and $56 \%$ is still a rain fed area.

iv. A major constraint to the development of agriculture in $\mathrm{J} \& \mathrm{~K}$ is the fact that only $50 \%$ of the ultimate irrigation potential of the state has been harnessed.

v. J\&K State is also deficient in rainfall; development of irrigation potential in the state becomes necessary for reducing dependence on import of food-grains and other agricultural products.

vi. Inadequate double cropping- due to lack of irrigation facility in some areas and climatic difficulty in others places. Only $56 \%$ of the net area is sown more than once.

vii. Small size of land holdings. 94\% of the land holdings fall in the size class of less than 2 hectare. More importantly the average holding size is 0.67 hectares as compared to 1.23 hectares in India as per latest agriculture census.

viii. Inadequate research in the field of agriculture in the state.

ix. Inadequate Agricultural Finance facilities.

Horticulture is no doubt contributing substantially to the State GDP but there are certain problems/weaknesses which are proving as hindrances for further growth of this sector. The problem areas are;

i. Absence of Post Harvest infrastructure - non-establishment of cold storages has locked the growth of this sector. At present, post harvest losses are estimated about 20-30\%. Experts say that there are losses to the extent of $10 \%$ at field level, $5 \%$ at transportation level, $2 \%$ during packaging, $9 \%$ at storage, $4 \%$ at 
processing level i.e. $30 \%$ in total. Surprisingly there is not even a single cold storage facility for apple preservation in the valley. The lack of this facility forces the farmers to sell their produce at cheaper rates.

ii. There is inadequacy of agro-processing facility. $30 \%$ of apple produced in the state are of low grade which can be processed for value addition rather than direct sale. This requires processing capacity of about 3 lakh tonnes per annum. The current capacity of approximately 65000 tonnes is not adequate. Demands in horticulture products can be sustained by developments in agro processing. In fact, there is rising demand for new products like dried powder, fruit based milk mix, juice pouches etc. and under these circumstances the private corporate sector can play a vital role in developing this aspect.

iii. Locational disadvantage is another issue of concern. The main consumption markets of the country are far away from production centers in the state. Lack of modern and efficient infrastructure like fast means of connectivity aggravates the problem of transporting the fruits especially of perishable nature to the main markets of the country.

iv. J\&K has unexploited capacity to produce products which have value demand and ready for attractive markets both in India and Overseas (e.g. bio aromatics, medicinal herbs, organic specialty vegetables etc.) To enable exploitation of these opportunities, major programmes are needed to educate farmers to change production habits and grow crops which the market will reward.

v. As a part of food habit, per capita consumption of meat, poultry items and milk is higher in J\&K state than all India, but the state is deficient in meat, poultry, eggs and milk production thus making state to heavily rely on imports from other states.

vi. Due to mismatch in demand and supply of mutton, the import of sheep and goat is continuously increasing. The import of sheep \& goat has increased by $71 \%$ when compared with such import figures of 1995-96.

vii. The state spends annually an average $` 700.00$ crores on the import of mutton and poultry from other states. Given the resources constraint nature of the economy, the State cannot bear this flight of capital.

\section{Appendix}

Table-1: Absolue Contribution of Primary and Non-primary Sectors in NSDP to State Economy (1981-2011)

\begin{tabular}{|c|c|c|c|c|c|}
\hline \multicolumn{2}{|c|}{$\begin{array}{c}\text { Primary Sector } \\
\text { (in Crores) }\end{array}$} & \multicolumn{2}{c|}{$\begin{array}{c}\text { Non-Primary Sector } \\
\text { (in Crores) }\end{array}$} & \multicolumn{2}{c|}{$\begin{array}{c}\text { NSDP } \\
\text { (in Crores) }\end{array}$} \\
\hline Cn.Prices & Ct.Prices & Cn.Prices & Ct.Prices & Cn.Prices & Ct.Prices \\
\hline 1798.04 & 497.44 & 1995.48 & 554.49 & 3793.52 & 1051.93 \\
\hline 1993.38 & 794.61 & 2452 & 1134.62 & 4445.38 & 1929.23 \\
\hline 1890.37 & 1258.89 & 3023.29 & 1649.37 & 4913.66 & 2908.26 \\
\hline 2387.08 & 2653.73 & 3644.4 & 4319.32 & 6031.48 & 6973.05 \\
\hline 2448.58 & 4729.5 & 5066.87 & 9598.9 & 7515.45 & 14328.4 \\
\hline 3775 & 7339.08 & 8522.25 & 17939.02 & 12297.3 & 25278.1 \\
\hline 3819.74 & 9225.98 & 13560.42 & 34490.4 & 17380.2 & 43716.4 \\
\hline
\end{tabular}

Sources:

Compiled from:

a) Digest of Statistics, Directorate of Economics and Statistics, J\&K Government, various issues.

b) State Domestic Product, Directorate of Economics and Statistics, J\&K Government, (1980-81 to 1996-97).

c) State Domestic Product, Directorate of Economics and Statistics, J\&K Government, (1993-94 to 1998-99).

d) The Economy of Jammu and Kashmir by Jasbir Singh.

e) Note: Constant prices at 1993-94 which has been calculated by Linking Factor Method.

i) $\mathrm{Cn}$. $=$ Constant

ii) $\mathrm{Ct}$. $=$ Current 
Changing Structure of Out-put \& Employment from Primary to Non-primary Sector of $J \& K$ Economy

Table 2: Classification of output and Workforce in J\&K State Economy Key Sector wise (1981-2011)

\begin{tabular}{|c|c|c|c|c|c|c|c|c|}
\hline & \multicolumn{4}{|c|}{ Workforce Key Sector wise } & \multicolumn{3}{c|}{ Out-put Key Sector wise(in Rs.crores) } \\
\cline { 2 - 10 } Sector & $\mathbf{1 9 8 1}$ & $\mathbf{1 9 9 1}$ & $\mathbf{2 0 0 1}$ & $\mathbf{2 0 1 1}$ & $\mathbf{1 9 8 1}$ & $\mathbf{1 9 9 1}$ & $\mathbf{2 0 0 1}$ & $\mathbf{2 0 1 1}$ \\
\hline $\begin{array}{c}\text { Primary } \\
\text { Sector }\end{array}$ & 1692813 & 1814830 & 1848233 & 1793021 & 1798 & 1890 & 2449 & 3820 \\
\hline $\begin{array}{c}\text { Non-Primary } \\
\text { Sector }\end{array}$ & 957177 & 1316470 & 1840642 & 2529692 & 1995 & 3023 & 5066 & 13559 \\
\hline Total & 2649990 & 3131300 & 3688875 & 4322713 & 3793 & 4913 & 7515 & 17379 \\
\hline
\end{tabular}

Sources:

Compiled from:

1) Census of India Various Issues.

2) Economic Survey, Planning \& Development Department, Govt. of Jammu \& Kashmir, various issues

3) Digest of Statistics, Planning \& Development Department, Govt. of Jammu \& Kashmir, various issues

\section{References}

[1]. Economic census, Govt. of India, various issues.

[2]. Digest of statistics; Directorate of Economics and Statistics; Govt. of J\&K, various issues.

[3]. Economic Survey; Directorate of Economics and Statistics; Govt. of J\&K, various issues.

[4]. Economic Review of J\&K; Directorate of Economics and Statistics; Govt. of J\&K, 2007-08

[5]. Strategizing Industrial Development in Jammu and Kashmir, Khursheed A. Butt, 2005.

[6]. $\quad 8^{\text {th }}$ Agriculture Census J \& K State, 2005-06.

[7]. The Economy of Jammu and Kashmir by Jasbir Singh

[8]. Ministry of Agriculture, Government of India, New Delhi

[9]. M.Phil Desertation "Comparative Study of Trends in production and Productivity of Major food Crops in Jammu and Kashmir,Punjab and Himachal Pradesh", by Naseer Hussain Bazaz, Kashmir university, 2010.

[10]. Reports, journals, magazines and news papers.

[11]. Ayazi, A.R. (1968). Inter relationship between Agriculture and other sector and their implication in terms of planning. Near East Commission on Agricultural Planning.

[12]. Bamzai, P.N.K. (2008). History of Kashmir, Gulshan Publishers Srinagar.

[13]. Beg, M.A. (1951). On the Way of Golden Harvests; Agricultural Reforms in Kashmir, Jammu and Kashmir Government.

[14]. Economic Review of Jammu and Kashmir, (2006-07). Directorate of Economics and Statistics, Planning and Development Department. Govt. of J \& K.

[15]. Gupta, N.S and Sing, A.J. (1979). Agricultural Development of States in India, Vol. I, Jammu and Kashmir.

[16]. Masoodi, M.A: Agriculture in Jammu and Kashmir - A Perspective.

[17]. NCAER. (1969). Techno-Economic survey of J\&K. National council of applied Economic research, New Delhi.

[18]. Nisar, A. (1978). Deteriorationg agrarian situation in Jammu and Kashmir, Easter Econmist.

[19]. In addition to the above sources relevant information has been collected from the following departments:

[20]. Directorate of Economics, Statistics \& planning, Govt. of Jammu and Kashmir, Srinagar.

[21]. Directorate of Sericulture, J\&K, Srinagar.

[22]. Directorate of Handicrafts, J\&K, Srinagar.

[23]. Directorate of Handlooms, J\&K, Srinagar.

[24]. Labour Commissioner, J\&K, Srinagar.

[25]. Financial Commissioner (Rev), J\&K, Srinagar.

[26]. D.F.O Forest Statics Division, Srinagar

[27]. Directorates of Animal Husbandry, J\&K, Srinagar. 